\title{
Pemberian Relaksasi Otot Progresif pada Lansia Dengan Hipertensi Essensial di Kota Jambi
}

\author{
Salvita fitrianti ${ }^{1}$, Miko Eka Putri \\ Program Studi Ilmu Keperawatan Stikes Baiturrahim Jambi ${ }^{1}$
}

\begin{abstract}
Based on health surveys, $30 \%$ of Indonesians are hypertensive. Hypertension is a risk factor for the third-leading cause of death after stroke and tuberculosis, i.e. $67 \%$ of the population of deaths at all ages. The number of an elderly female with essential hypertension at the public health center Simpang Kawat Jambi city year 2017 as many as 191 people. This study aimed to determine is there the effect of giving progressive muscle relaxation techniques toward changes in blood pressure in elderly with essential hypertension. This study used one group pre-post test design method; it used simple random sampling technique, numbers of samples were 20 respondents. This study was conducted at Auditorium the public health center Simpang Kawat Jambi city from July 24th - 30th 2017. The instruments are Blood pressure measurement results, data analyzed as univariate and bivariate. The findings indicated that $p$-value Systole blood pressure $p$-value $=0.000$ and diastole $p$-value $=0.000$, so it can conclude that there is the significant effect of Changes in blood pressure in the elderly with essential hypertension before and after the technique of progressive muscle relaxation at the public health center Simpang Kawat Jambi city. It expected to Health workers can provide knowledge about progressive muscle relaxation technique exercises so that people with essential hypertension can control blood pressure independently at home.
\end{abstract}

Keywords: Progressive Muscle Relaxation Techniques, Essential Hypertension, Elderly

\section{PENDAHULUAN}

Semakin meningkatnya arus globalisasi di segala bidang, perkembangan teknologi dan industri telah banyak membawa perubahan pada prilaku dan gaya hidup masyarakat, serta situasi lingkungan misalnya perubahan pola konsumsi makanan, berkurangnya aktivitas fisik dan meningkatnya polusi lingkungan. Perubahan tersebut tanpa disadari telah memberi pengaruh terhadap perubahan tingkat kesehatan yang memicu transisi epidemiologi penyakit degeneratif atau penyakit tidak menular. Salah satu penyakit tidak menular adalah hipertensi (tekanan darah tinggi). Tekanan darah adalah desakan darah terhadap dinding arteri ketika darah tersebut dari jantung ke jaringan. Tekanan ini bervariasi sesuai pembuluh darah terkait dan denyutan jantung (Depkes RI, 2008).

WHO menetapkan hipertensi sebagai faktor risiko nomor tiga etiologi kematian di dunia. Hipertensi bertanggung jawab terhadap $62 \%$ timbulnya kasus stroke, $49 \%$ timbulnya serangan jantung. Berdasarkan survey kesehatan, $30 \%$ penduduk Indonesia mengalami hipertensi. Hipertensi merupakan faktor resiko ketiga penyebab kematian setelah penyakit stroke dan tuberkolosis yakni $67 \%$ dari populasi kematian pada semua umur.

Lansia merupakan kelompok yang rentan sekali terkena penyakit menular ataupun tidak menular karena dengan bertambahnya umur seseorang akan mengalami penurunan atau perubahan fungsi seperti fisik, psikis, biologis, spiritual, serta hubungan sosialnya, dan tentunya memberikan pengaruh terhadap berbagai aspek kehidupanya,salah satunya kondisi kesehatanya, World Population Prospect (2010) dalam KemenKesRI (2013) menyebutkan bahwa populasi lansia di dunia pada tahun 2010 mencapai $14,35 \%$ dari total penduduk dunia.

Hipertensi adalah penyakit yang paling banyak di derita oleh lansia di 
indonesia dibuktikan dengan hasil Riskedas 2013 tentang 10 masalah kesehatan lansia yang tercantum di InfoDATIN Situasi Lanjut Usia (pusat data dan informasi kementrian kesehatan RI) di Indonesia bahwa penyakit Hipertensi menempati urutan pertama sebagai penyakit lansia yaitu dengan prevalensi usia 55 - 64 tahun sebanyak $45,9 \%$, usia 65 - 74 tahun sebanyak $57,6 \%$, dan usia $75+$ tahun sebanyak $63,8 \%$.

Pada orang lanjut usia penyebab hipertensi disebabkan terjadinya perubahan pada penurunan elastisitas dinding aorta, katup jantung menebal dan menjadi kaku, kemampuan jantung memompa darah, kehilangan elastisitas pembuluh darah dan meningkatnya resistensi pembuluh darah perifer. Setelah usia 20 tahun kemampuan jantung memompa darah menurun $1 \%$ tiap tahun sehingga menyebabkan menurunya kontraksi dan volume (Aspiani,2014).

Selain penurunan fisiologis sistem kardiovaskuler seorang lanjut usia juga telah menghadapi banyak situasi yang penuh tekanan dalam kehidupan seharihari yang menimbulkan respons stres.

Relaksasi dan teknik manipulasi pikiran mengurangi komponen fisiologis dan emosional stress. Relaksasi bertujuan untuk memberikan rasa nyaman, memperbaiki disfungsi fisik, mengubah respon fisiologis, dan mengurangi rasa takut yang terkait dengan penyakitnya. Relaksasi akan membuat individu lebih mampu menghindari reaksi yang berlebihan karena adanya stres sehingga dengan melakukan relaksasi dapat mengurangi tekanan darah, detak jantung jadi lebih rendah dan tidur menjadi nyenyak (Potter, 2006).

Salah satu teknik relaksasi yang sering digunakan adalah teknik Relaksasi Otot Progresif (Progressive Muscular Relaxation [PMR]) sebagai terapi untuk membantu meredakan beberapa gejala yang berkaitan dengan stress, seperti Insomnia dan Hipertensi. Teknik ini mungkin lebih unggul dari teknik lain, memperlihatkan pentingnya menahan respon stress dengan mencoba meredakan ketegangan otot secara sadar.(Widyastuti, 2003).

Data dari Dinas Kesehatan Kota Jambi bahwa penderita hipertensi pada lansia di Kota Jambi dari 20 Puskesmas di dapatkan nilai tertinggi berada di wilayah kerja Puskesmas Simpang Kawat dengan angka penderita 2.029 orang atau $13,85 \%$. Berdasarkan survei awal penelitian yang dilakukan di Puskesmas Simpang Kawat Kota Jambi, diperoleh gambaran bahwa 10 pasien lansia dengan hipertensi esenssial yang melakukan kunjungan, Para penderita hipertensi mengatakan hanya mengkonsumsi obat anti-hipertensi seperti amlodhipin dan tidak mengetahui cara mengatasi secara non farmakologis untuk mengurangi nyeri dalam beraktivitas. Kebanyakan masih mengalami nyeri tengkuk, lemas, kadang sesak didada dan pusing serta sulit tidur dimalam hari. Ketika peneliti bertanya tentang pola makan sehari - hari dirumah, 3 dari lansia menjawab mereka masih sangat menyukai daging merah seperti daging sapi, 7 dari mereka menjawab tidak mengonsumsi daging merah lagi, sedangkan dari ke 10 lansia masih mengonsumsi garam dalam makananya sehari - hari. Selanjutnya peneliti bertanya tentang aktivitas mereka sehari-hari 9 dari lansia tersebut mengatakan hanya duduk dirumah dan bermain dengan cucu ketika cucunya pulang sekolah, 1 lansia mengatakan kadang berolahraga di pagi dan sore hari seperti berjalan di kompleks tempat tinggalnya. Mereka belum mengetahui tentang Terapi Relaksasi Otot progresif, baik cara ataupun manfaatnya untuk menurunkan tekanan darah.

Berdasarkan latar belakang di atas, maka rumusan masalah dalam penelitian ini adalah "Bagaimana pengaruh pemberian teknik relaksasi otot progresif terhadap perubahan tekanan darah pada lanjut usia dengan hipertensi essensial di Wilayah Kerja Puskesmas Simpang Kawat Kota Jambi?". 
Tujuan dari penelitian adalah untuk mengetahui rata-rata tekanan darah pada lansia dengan hipertensi esenssial sebelum dan sesudah diberikan teknik relaksasi otot progresif, dan mengetahui pengaruh pemberian teknik relaksasi otot progresif terhadap tekanan darah pada lansia dengan hipertensi esenssial di Wilayah Kerja Puskesmas Simpang Kawat Kota Jambi.

\section{METODE PENELITIAN}

Desain penelitian yang digunakan dalam penelitian ini adalah pre experiment dengan metode pendekatan one group pre - post test design design yaitu untuk melihat pengaruh pemberian teknik relaksasi otot progresif terhadap perbedaan tekanan darah pada lansia dengan hipertensi esensial. Rancangan ini memberikan perlakuan terhadap semua responden secara bersamaan, diawali dengan pengukuran tekanan darah (pretest), dan setelah diberikan perlakuan dilakukan pengukuran tekanan darah kembali (post-test), pengukuran tekanan darah dalam penelitian ini menggunakan sphygnomanometer air raksa. Intervensi relaksasi otot progresif dalam penelitian ini dilakukan sebanyak satu kali/hari selama satu seminggu dengan lama waktu intervensi 10-30 menit,tempat penelitian Aula Puskesmas Simpang Kawat Kota Jambi. Sampel dalam penelitian ini adalah 20 responden lansia berjenis kelamin perempuan dengan hipertensi esensial yang berobat di Puskesmas Simpang Kawat Kota Jambi yang telah memenuhi kriteria inklusi. Teknik pengambilan sampel yang digunakan yaitu Simple Random Samping teknik ini digunakan apabila populasi dari mana sampel diambil merupakan populasi homogen yang hanya mengandung satu ciri. Dengan demikian sampel yang dikehendaki dapat diambil secara sembarang (acak) saja (Arikunto, 2009).

Analisis data yang digunakan dalam penelitian ini meliputi analisis univariat dan bivariat yang apabila hasil $\mathrm{P}$ value $\leq \alpha$ $(0,05)$, maka Ho ditolak artinya kedua variabel terdapat pengaruh yang signifikan dan sebaliknya jika $\mathrm{P}$ value $>\alpha(0,05)$, maka Ho diterima artinya kedua variabel tidak terdapat pengaruh yang signifikan.

\section{HASIL DAN PEMBAHASAN}

Hasil penelitian yang telah dilakukan pada tanggal 24-30 Juli 2017 di Puskesmas Simpang Kawat Kota Jambi dengan 20 responden tentang pengaruh teknik relaksasi otot progresif terhadap perubahan tekanan darah pada lansia dengan hipertensi esensial. Adapun hasil yang diperoleh adalah sebagai berikut:

\section{Analisa Univariat}

Distribusi responden berdasarkan karakteristik:

Gambar 1

Karakteristik umur responden

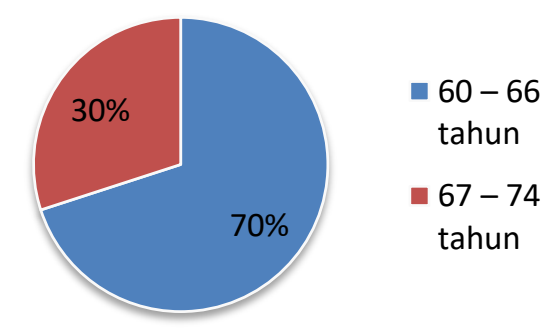

Berdasarkan gambar 1 diketahui bahwa sebanyak 14 orang responden dengan persentase $(70,0 \%)$ berumur $60-66$ tahun.

Gambar 2

Karakteristik jenis kelamin responden

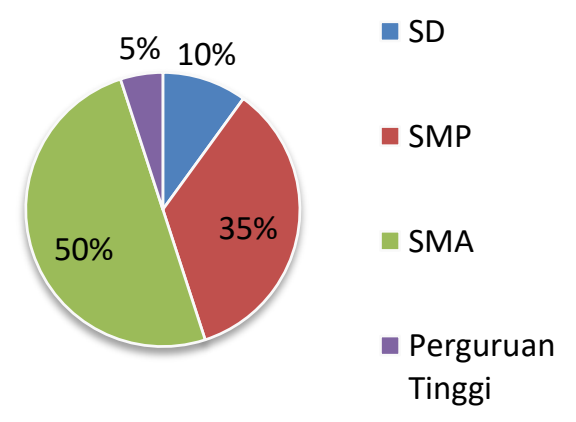


Berdasarkan gambar 2 diketahui bahwa sebanyak 10 orang responden dengan persentase $(60,0 \%)$ memiliki pendidikan terakhir pada jenjang SMA sederajat.

Gambar 3

Karakteristik pekerjaan responden

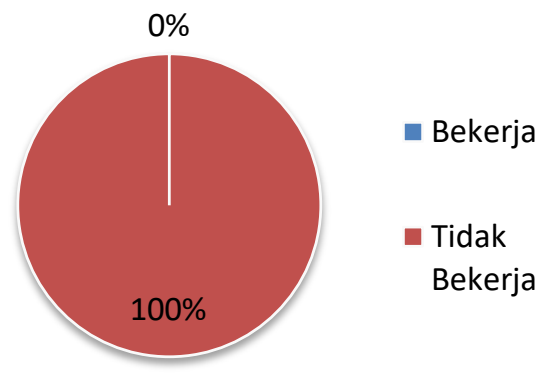

Berdasarkan gambar 3 diketahui bahwa sebanyak 20 orang responden dengan persentase $(100,0 \%)$ tidak bekerja.

Hasil analisis univariat pada gambaran tekanan darah sebelum dan sesudah di berikan teknik relaksasi oto progresif yaitu nilai rata-rata tekanan darah sistole mengalami penurunan dari 149,25 $\mathrm{mmHg}$ menjadi $118,50 \mathrm{mmHg}$, Pada nilai rata-rata tekanan darah diastole mengalami penurunan dari $97,50 \mathrm{mmHg}$ menjadi $86,50 \mathrm{mmHg}$.

\section{Analisa Bivariat}

Analisa ini untuk melihat pengaruh latihan teknik relaksasi otot progresif terhadap perubahan tekanan darah pada lansia dengan hipertensi esensial. Analisis bivariat ini mengguanakan uji Paired t-test dengan tingkat kemaknaan sebesar 95\% atau $\alpha=0,05$. Hasil analisis bivariat dapat dilihat pada tabel 1 sebagai berikut:

\begin{tabular}{ccccc}
\hline $\begin{array}{c}\text { Variabel } \\
\text { Tekanan } \\
\text { Darah) }\end{array}$ & N & Mean & SD & $\begin{array}{c}\text { P } \\
\text { value }\end{array}$ \\
\hline Sistole & 20 & 30,75 & 7,48 & 0,000 \\
Diastole & 20 & 11,00 & 9,12 & 0,000 \\
\hline
\end{tabular}

Berdasarkan tabel 1 didapatkan nilai rata-rata pada tekanan darah sistole dan diastole dari 20 responden sebelum dan sesudah diberikan latihan teknik relaksasi otot progresif sebesar $30,75 \mathrm{mmHg}$ pada tekanan darah sistole, sedangkan pada tekanan darah diastole nilai rata-ratanya sebesar 11,00 mmHg. Dari hasil uji statistik dengan menggunakan Uji paired $t$ test didapatkan $\mathrm{p}$-value $=0,000 \leq \alpha(0,05)$ pada tekanan darah sistole maupun diastole, maka dapat disimpulkan bahwa ada pengaruh yang signifikan terhadap penurunan tekanan darah pada lansia dengan hipertensi esensial sebelum dengan sesudah diberikan teknik relaksasi otot progresif di Puskesmas Simpang Kawat Kota Jambi.

Hasil penelitian ini berbanding lurus dengan teori yang mengatakan bahwa menciptakan keadaan rileks seperti melakukan latihan teknik relaksasi otot progresif adalah salah satu cara penatalaksanaan hipertensi secara non farmakologis (Widyanto,2013). Karena teknik relaksasi otot progresif bekerja dengan cara memusatkan perhatian pada suatu aktivitas otot dengan mengidentifikasikan otot yang tegang kemudian menurunkan ketegangan dengan melakukan teknik relaksasi untuk mendapatkan perasaan rileks. (Herodes, 2010).

Penurunan tekanan darah pada pasien lansia dengan hipertensi esensial sesudah diberikan latihan teknik relaksasi otot progresif ini sesuai dengan apa yang dikemukakan oleh Asmadi (2008) relaksasi otot progresif merupakan salah satu terapi nonfarmakoterapi yang tidak memerlukan imajinasi, sugesti, tidak ada efek samping, mudah untuk dilakukan. Relaksasi otot progresif merupakan salah satu teknik untuk mengurangi ketegangan otot dengan proses yang simpel dan sistematis dalam menegangkan sekelompok otot kemudian merilekskanya kembali sehingga otot-otot menjadi relaks dan menurunkan kecemasan/stres sehingga menyebabkan tekanan darah menurun pada hipertensi. 
Dengan melakukan teknik relaksasi otot progresif maka lansia akan merasakan keadaan rileks menyeluruh, mencakup keadaan rileks secara fisiologis, secara kognitif dan secara behavioral. Secara fisiologis, keadaan rileks ini akan menurunkan tingkat kecemasan dan stres yang dialami pasien dengan hipertensi esensial. Karena Selama seseorang stres maka hormon-hormon seperti epineprin dan nonepinephrin, kortisol, glukagon, ACTH, kortikosteroid, dan tiroid akan meningkat. Nonepinephrine yang merupakan suatu vasocontrictor yang akan bekerja pada arteri kecil dan arteriola untuk menigkatkan resistensi peripheral sehingga tekanan darah meningkat. (Price dan Wilson, 2002, dalam Masriadi, 2016). Teknik relaksasai otot progresif ini akan mengaktivasi kerja sistem saraf parasimpatis dan memanipulasi hipotalamus melalui pemusatan pikiran untuk memperkuat sikap positif sehingga rangsangan stres terhadap hipotalamus berkurang. Aktivasi dari sistem saraf parasimpatis disebut juga Trophotropic yang dapat menyebabkan perasaan ingin istirahat, dan perbaikan fisik tubuh. Respon parasimpatik meliputi penurunan denyut nadi dan tekanan darah serta meningkatkan aliran darah. Oleh sebab itu, melalui latihan relaksasi lansia dilatih untuk dapat memunculkan respon relakasasi sehingga dapat mencapai keadaan tenang dan rileks sehingga lansia mengalami penurunan tekanan darah. (Sucipto, 2014).

Pembahasan diatas didukung oleh Hasil penelitian yang dilakukan oleh Yulinda (2012) dengan judul Perbedaan Pengaruh Terapi Napas Dalam Dan Terapi Relaksasi Otot Progresif Terhadap Penurunan Tekanan Darah Lansia Hipertensi Di Posyandu Lansia Kelurahan Surau Gadang Kecamatan Nanggalo Padang Tahun 2012 dengan hasil penelitian menunjukan terdapat penurunan tekanan darah pada masing - masing kelompok dengan $\mathrm{p}=0,000$ dan terdapat perbedaan penurunan tekanan darah antara kelompok terapi napas dalam dan terapi relaksasi otot progresif dengan $\mathrm{p}=0,001$ sistolik dan $p=0,042$. Kesimpulanya terapi relaksasi otot progresif lebih baik dalam menurunkan tekanan darah pada lansia dengan hipertensi dibandingkan dengan terapi napas dalam.

Dari hasil pembahasan dalam penelitian ini dapat disimpulkan bahwa teknik relaksasi otot progresif berpengaruh terhadap perubahan tekanan darah pada lansia dengan hipertensi esensial, jika dilakukan dengan benar meliputi benar gerakan, benar urutan gerakannya, benar posisi dan juga dilakukan ditempat yang tenang dan tertutup sehingga dalam melaksanakan teknik relakasasi otot progresif responden benar-benar merasakan rileks. Didalam penelitian ini latihan teknik relaksasi otot progresif dilakukan di Aula Puskesmas Simpang Kawat Kota Jambi, yang bersih, nyaman, tidak ada suara bising dan tidak ada aktivitas keluar masuk ruangan, artinya tempat penelitian ini sangat sesuai untuk melakukan teknik relaksasi otot progresif dan kesungguhan serta keseriusan seluruh responden dalam melaksanakan latihan teknik relaksasi otot progresif sangat terlihat dalam penenlitian karena seluruh responden bisa melakukan seluruh gerakan dengan baik dan benar sesuai dengan yang di instruksikan oleh peneliti sebagai instruktur latihan teknik relaksasi otot progresif, sehingga penelitian yang berjalan selama seminggu ini berjalan kondusif. Selama pelaksanaan latihan juga diiringi oleh musik instrumental, karena alunan musik dapat mengubah ambang otak yang dalam keadaan stres menjadi lebih adaptif secara fisiologis dan efektif. sehingga terciptalah keadaan rileks yang menyeluruh, mencakup keadaan rileks secara fisiologis, secara kognitif dan behavioral. Keadaan rileks yang tercipta dari latihan teknik relaksasi otot progresif akan menyebabkan penuruanan kadar efinefrin maupun non-epinefrin, sehingga berdampak pada menurunya frekuensi denyut jantung, gerakan teknik relaksasi otot progresif juga dapat menurunkan 
ketegangan otot yang berdampak pada vasodilatasi pembuluh darah sehingga tekanan darah pada lansia dengan hipertensi esensial setelah melakukan latihan teknik relaksasi otot progresif selama seminggu mengalami penurunan tekanan darah yang signifikan.

\section{SIMPULAN}

Kesimpulan dalam penelitian ini yaitu terdapat pengaruh latihan teknik relaksasi otot progresif terhadap perubahan tekanan darah sistole dan diastole pada responden lansia penderita hipertensi esensial dengan $\mathrm{p}$-value $=0,000$ atau $<\alpha(0,05)$.

Berdasarkan hal tersebut maka diharapkan bisa menjadi sebagai bahan masukan bagi Puskesmas Simpang Kawat Kota Jambi untuk meningkatkan pemberian asuhan keperawatan pada pasien lansia dengan Hipertensi esensial dengan cara pemberian pengetahuan tentang latihan teknik relaksasi otot progresif maupun kegiatan seperti pelatihan teknik relaksasi otot progresif minimal 2 kali seminggu agar penderita Hipertensi esensial dapat mengontrol tekanan darah secara nonfarmakologis sehingga pasien tidak ketergantung lagi dengan obat anti hipertensi. Pada penelitian selanjutnya dapat dikembangkan dengan dengan meningkatkan lama waktu penelitian serta topik permasalahan yang sama tetapi menambah variabel seperti seperti perubahan BB dan frekuensi napas pada lansia dengan hipertensi esensial.

\section{DAFTAR PUSTAKA}

Arikunto, Suharsimi, 2009. Manajemen Penelitian. Jakarta: Rinneka Cipta.

Ariyani, 2007. Terapi Modalitas Keperawatan.Jakarta: EGC

Asmadi, 2008. Teknik Prosedural Konsep \& Aplikasi Kebutuhan Dasar Klien. Penerbit Salemba Medika. Jakarta

Aspiani, 2014. Buku Ajar Asuhan Keperawatan Klien Gangguan Kardiovaskular. Jakarta: EGC
Balitbangkes Kemenkes RI, 2013, Riset Kesehatan Dasar-Riskesdas 2013,Kemenkes RI, Jakarta.

Departemen Kesehatan RI. (2014). Profil Kesehatan Provinsi Jambi 2014.

$w w w$.depkes.go.id/profil/PROFIL_KES... /05_Jambi_2014 diperoleh tanggal 30 Desember 2016, pada pukul 18.45 WIB.

Fajria. (2012). Perbedaan Pengaruh terapi napas dalam dan teknik relaksasi otot progresif terhadap penurunan tekanan darah lansia hipertensi di posyandu lansia kelurahan sungai gadang kecamatan nanggalo padang. Jurnal Keperawatan. Universitas Riau. Riau.

Jauhar, Bararah, 2013. Asuhan Keperawatan Panduan Lengkap Menjadi Perawat Professional. Jakarta: Prestasi Pustaka.

Masriadi, 2016, Epidemiologi Penyakit Tidak Menular, Jakarta: TIM.

Muhith, Abdul, 2016. Pendidikan Keperawatan Gerontik. Yogyakarta: Andi Offset .

Muttaqin, Arif. (2009). Buku Ajar Asuhan Keperawatan Klien dengan Gangguan Sistem Kardiovaskular dan Hematologi. Jakarta. Salemba Medika.

Nair dan Peatte, 2015. Dasar-dasar Patofisiologi Terapan, Panduan Penting Mahasiswa Keperawatan dan Kesehatan, Ed. 2, Cetakan. Ke 1. Jakarta: Bumi Medika.

Nasrullah, Dede, 2016. Buku Ajar Keperawatan Gerontik Jilid I, Dengan Pendekatan Asuhan Keperawatan Nanda NIC Dan NOC. Jakarta: TIM.

Nurhaliza, 2015. Pengaruh Latihan Relaksasi Otot Progresif Terhadap Penurunan Tekanan Darah Pada Penderita Hipertensi Primer di Dusun Gondang Surakarta 2015.

Nursallam, 2008. Konsep Dan Penerapan Metodologi Penelitian Ilmu Keperawatan, Pedoman Skripsi, Tesis Dan Instrument Penelitian 
Keperawatan. Jakarta: Salemba Medika.

Notoatmodjo, Soekidjo, (2012),

Metodologi Penelitian Kesehatan, Jakarta: Rineka Cipta.

Potter \& Perry, 2010. Fundamental Keperawatan, Ed. 7. Jakarta: Salemba Medika. 2006. Buku Ajar Fundamental Keperawatan- Volume 1. Pnerbit EGC. Jakarta.

Setyoadi \& Kushariyadi, 2011. Terapi Modalitas Keperawatan Pada Klien Psikogeriatri. Jakarta: Salemba Medika.

Sucipto. (2014). Perbedaan Pengaruh teknik relaksasi otot progresif terhadap tekanan darah pada lansia hipertensi di desa karangbendo banguntapan bantul yogyakarta. Jurnal Keperawatan. Universitas Muhamadiyah Yogyakarta. Yogyakarta.

Sugiyono, 2012. Metode Penelitian Pendidikan (Pendekatan Kuantitatif, Kualitatif, Dan $R$ \& D). Jakarta: Alfabet, CV.

Smeltzer, S.C. dan Bare B.G., 2002, Buku Ajar Keperawatan Medikal Bedah, Volume 2, Ed. 8, , Jakarta : EGC.

Udjianti, Wayan Juni, (2011), Keperawatan Kardiovaskular, Jakarta Selatan : Salemba Medika.

Widyanto,dkk, 2013. Trend Disease "Trend Penyakit Saat Ini". Jakarta: TIM.

Widyastuti, 2003. Manajemen Stress. 116 Hal. Jakarta: EGC. 